\title{
Application and limitation of molecular data and essential oil content in identification of Leutea elbursensis Mozaff in northern Iran
}

\author{
Samane-Sadat Emami-Tabatabaei ${ }^{1}$, Kambiz Larijani $^{2}$, Iraj Mehregan ${ }^{1 *}$ \\ ${ }^{1}$ Department of Biology, Science and Research branch, Islamic Azad University, Tehran, Iran \\ ${ }^{2}$ Department of Chemistry, Science and Research branch, Islamic Azad University, Tehran, Iran
}

\begin{abstract}
In this paper, the internal transcribed spacer (ITS) sequences, genetic structure and the chemical composition of essential oils of four populations belonging to Leutea elbursensis and Leutea petiolaris, two species endemic to northern Iran, are analyzed. Phylogenetic analysis based on the ITS data showed that all accessions of L. elbursensis formed a monophyletic clade, and L. elbursensis was a sister to the rest of Leutea species. Results of amplified fragment length polymorphism (AFLP) analysis performed on the total genome showed that all individuals presented in the study belonged to two different genetic clusters. The individuals belong to L. petiolaris had a different genetic structure and yielded no traceable amount of essential oils. The essential oil obtained from the ripe fruits of $L$. elbursensis yielded $0.5-0.6 \%$ of volatile essential oils. In total, 15-29 volatile natural components were identified on the basis of their mass spectra characteristics and retention indices, in which $\alpha$-pinene (33.18-43.22\%), $\beta$-pinene (32.4-40.9\%) were the major constituents. Our results indicate that L. elbursensis is a distinct species, segregated from the other species based on morphology, ITS data and AFLP profile. In addition, despite the relatively uniform genetic structure of L. elbursensis, the chemical composition of essential oil could be highly affected by different factors.
\end{abstract}

Keywords: chemotaxonomy, Iran, phylogeny, $\alpha$-pinene, $\beta$-pinene

\section{Introduction}

Plants are an important component of traditional food, but are also central to healthy diets of the modern urban population (Benjak et al. 2005, Ercisli 2009, Ercisli et al. 2010, Rop et al. 2014, Canan et al. 2016, Zorenc et al. 2016). Essential oils obtained from plants have applications in food, chemistry, pharmacy, medicine and perfumery (Hay and Waterman 1993, Mehregan and Ghannadi 2013). Members of the family Apiaceae (Umbelliferae) are well known for the production of essential oils with high pharmaceutical and economic value (Olivier and van Wyk 2013). Based on the most recent researches, the plant family Apiaceae with about 430 genera and 3800 species has a worldwide distribution, especially in the northern hemisphere (Stevens 2012). Apiaceae has about 110 genera and 400 species distributed in Iran (Mozaffarian 2007). The genus Leutea Pimenov belongs to the "Ferula group" including Ferula L., Dorema L. and Leutea (Kurzyna-Młynik et al. 2008). The genus Ferula includes more than 170 species distributed in central and southwestern Asia, and the Mediterranean region including northern Africa (Pimenov and Leonov 1993, Kurzyna-
Młynik et al. 2008). It has about 30 aromatic species in Iran (Mozaffarian 2007). The genus Dorema has seven species in Iran (Mozaffarian 2007). The taxonomic status of Leutea is more complex. The genus Leutea with its few species is limited to SW Asia (Pimenov 1987). The taxonomy of the group has changed considerably, especially since publication of Flora Iranica, volume 162 (Pimenov 1987). The type of the genus, i.e. Leutea petiolaris was first effectively published as part of the genus Ferula as F. petiolaris DC. (de Candolle 1830). Boissier (1872) integrated L. petiolaris with other species of the genus Peucedanum L. sect. Juncea. He described two other new species, which are today known to be part of Leutea. Pimenov (1987) transferred all six known species of the group to the new genus named Leutea Pimenov. Spalik and Downie integrated the whole Leutea species into the genus Ferula (see Kurzyana-Mlynik et al. 2008). Recent works of Panahi et al. (2015) suggested that species of Leutea should be re-established from Ferula again.

Leutea elbursensis Mozaff. (syn.: Ferula elbursensis (Mozaff.) Spalik et. S. R. Downie), an endemic to northern Iran,

*Corresponding author, e-mail: iraj@daad-alumni.de; imehregan@srbiau.ac.ir 
is a glabrous perennial tough herb, 1.5 to $3 \mathrm{~m}$ high, with compound pinnate leaves with tubular lobes. It has compound umbels consisting of yellow 5-merous flowers. The fruits are schizocarp, compressed, elliptic and up to $10 \times 4 \mathrm{~mm}$ in size (Mozaffarian 2007, Kanani et al. 2013). L. elbursensis can be distinguished from the other species by its narrow pedicels, ovate-elliptic fruits, greenish-yellow petals, and large and strong habits (Mozaffarian 2007). Despite the recent publication date of its name, many populations of L. elbursensis have been known for a long time. Material of L. elbursensis was first considered part of L. cupularis (Pimenov 1987), and was later segregated from it by Mozaffarian in 2003 (Kurzyna-Młynik et al. 2008). Mozafarian (2007) identifield two different species in the north of Iran (Tehran province) i.e. L. petiolaris and L. elbursensis. These taxonomic complexities have resulted in ambiguity attaching to those works already performed on three species L. elbursensis, $L$. cupularis and L. petiolaris (Masoudi et al. 2004, KurzynaMłynik et al. 2008, Alipour et al. 2015).

Members of the family Apiaceae in Iran are widely studied for their essential oil contents (Olivier et al. 2013, Safaeian et al. 2015). Most of those studies are single records based on the material collected from a single locality. Chemical composition of the essential oils depends on many factors such as collection time, geographical locality and genetic structure (Munoz-Bertomeu et al. 2007). Therefore, a single report of essential oil composition for a given species could not be generalized for all of its populations. Looking for their chemotaxonomic value, Kanani et al. (2011) studied chemical composition of the essential oils for 18 Ferula species from Iran.

Since its introduction in 1995, amplified fragment length polymorphism (AFLP) has become a popular research tool for detecting genetic structure of populations as well as differences at intra-species level (Vos et al. 1995).

In this paper we try to find out if different populations growing wild in the north of Iran (Tehran province) belong to the same species. Material from the western part of the province was previously identified as L. elbursensis by Mozaffarian (2007). We used analysis of ITS (internal transcribed spacer) of the nuclear genome to find the phylogenetic placement of those plants. In addition, AFLP fingerprinting techniques are used for distinguishing the genetic structures of different populations. We also aim to study the possible correlation between the genetic structure and the essential oil profile of $L$. elbursensis populations collected from different localities in northern Iran (Tehran province), using GC/MS and AFLP fingerprinting techniques. Finally, we will try to clarify the taxonomic position of L. elbursensis.

\section{Materials and methods}

Between August and September 2013, plants from three populations of L. elbursensis and one population of $L$. petiolaris were collected from northern Iran, the province of Tehran (Tab. 1). Plant materials were identified by authors after Mozaffarian (2007) and vouchers were deposited in the herbarium of Islamic Azad University, Science and Research branch, Tehran, Iran (IAUH).

Fresh leaf fragments from at least six individuals from each population ( 24 individuals in total) were taken and gradually dried in silica-gel pearls. Total DNA was extracted for each individual sampled using NucleoSpin ${ }^{\circledR}$ Plant II kit after the manufacturer's manual (Machery-Nagel, Dueren, Germany). The complete internal transcribed spacer (ITS) region of the DNA was amplified using the primer pair AB101 (5'- ACG AAT TCA TGG TCC GGT GAA GTG TTC G - 3') and AB102 (5'-TAG AAT TCC CCG GTT CGC TCG CCG TTA C - 3') (Douzery et al. 1999), in a PCR reaction under the following conditions: a pretreatment of 5 minutes at $95^{\circ} \mathrm{C}, 35$ cycles of 30 seconds at $95^{\circ} \mathrm{C}, 30 \mathrm{sec}$ onds at $50^{\circ} \mathrm{C}$, and 1 minute 30 seconds at $72^{\circ} \mathrm{C}$, and a final extension of 7 minutes at $72^{\circ} \mathrm{C}$. The complete ITS region was sequenced on an ABI 3730 sequencer machine (Applied Biosystems, Waltham, Massachusetts, USA). Sequences were visually checked and edited with Sequencher 4 (Gene Codes Corporation, Ann Arbor, MI USA), and then aligned using MacClade 4.08 (Maddison and Maddison 2000), alongside additional sequences taken from the GeneBank. Ferula violacea Korovin and F. olivacea (Diels) H. Wolff. were chosen as outgroup taxa after Panahi et al. (2015). Maximum parsimony (MP) analysis of the ITS dataset was performed with PAUP* (Swofford 2002). Bayesian analysis (BA) of the ITS dataset was performed using MrBayes v3.1.2 (Huelsenbeck and Ronquist 2001).

The AFLP ${ }^{\mathrm{Tm}}$ procedure for this work followed Vos et al. (1995), and Scalone et Albach (2012) with the following modifications: three primer combinations used for selective PCR were E38- ${ }^{\text {HEX }}$ labelled (5' - GAC TGC GTA CCA ATT CAC T - 3') combined with M57 (5'- GAT GAG TCC TGA GTA ACG G - 3'), E45- ${ }^{\text {FAM }}$ labelled (5'-GAC TGC GTA CCA ATT CAT G - 3') combined with M54 (5' - GAT GAG TCC TGA GTA ACC T - 3'), and E40- ${ }^{\text {NED }}$ labelled (5'- GAC TGC GTA CCA ATT CAG C - 3') with M55 (5'-GAT GAG TCC TGA GTA ACG A - 3'). PCR products of each sample were combined equally, and $2 \mu \mathrm{l}$ of this multiplex product was run with $7.75 \mu \mathrm{l} \mathrm{HiDi}$ formamide (Applied Biosystems) and 0.25 $\mu \mathrm{l}$ internal size standard GeneScan ROX (Applied Biosystems) on an ABI 3730 automated capillary sequencer. Fragments were analyzed and scored using GeneMarker 2.4.1 (SoftGenetics). Structure 2.3.4 (Pritchard et al. 2000) was used for analyzing the genetic structure of populations. An analysis of molecular variance (AMOVA) test was performed using GenAlEx 6.5 (Peakall and Smouse 2012).

$100 \mathrm{~g}$ of the ripened and dried fruits of the plant for each population were chopped in distilled water and a hydro-distilled fraction of it was isolated by hydrodistillation for 3 hours. We used a Hewlett Packard 5972A mass selective detector coupled with a Hewlett Packard 6890 gas chromatograph, equipped with a cross-linked 5\% PH ME siloxane HP$5 \mathrm{MS}$ capillary column $(50 \mathrm{~m} \times 0.25 \mathrm{~mm}$, film thickness 0.32 $\mu \mathrm{m})$ for gas chromatography-mass spectrometry (GC-MS) analysis. The following GC operating conditions were used:

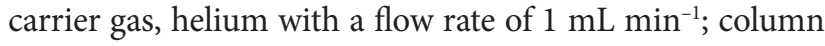


Tab. 1. Populations of Leutea elbursensis from northern Iran included in the molecular and phytochemical analysis with voucher information and GenBank accession numbers.

\begin{tabular}{|c|c|c|c|c|}
\hline No. & Species & Locality & Herbarium number & $\begin{array}{l}\text { Genbank } \\
\text { number }\end{array}$ \\
\hline 1 & Leutea elbursensis Mozaff. & $\begin{array}{l}\text { Iran: Tehran, Emamzadeh-Davoud, } \\
35.898,51.288,2400 \mathrm{~m}\end{array}$ & Emami 14391 (IAUH) & KP793684 \\
\hline 2 & Leutea elbursensis Mozaff. & $\begin{array}{l}\text { Iran: Tehran, Morad-Abad, 35.796, } \\
\text { 51.322, } 1800 \mathrm{~m}\end{array}$ & $\begin{array}{l}\text { Emami } 14393 \\
\text { (IAUH) }\end{array}$ & KP793683 \\
\hline 3 & Leutea elbursensis Mozaff. & $\begin{array}{l}\text { Iran: Tehran, Hesarak } \\
35.796,51.305,1700 \mathrm{~m}\end{array}$ & Emami 14394 (IAUH) & KP793686 \\
\hline 4 & Leutea petiolaris (DC.) Pimenov & $\begin{array}{l}\text { Iran: Tehran, Dizin, } \\
36.043,51.441,3400 \mathrm{~m}\end{array}$ & $\begin{array}{l}\text { Emami } 14392 \\
\text { (IAUH) }\end{array}$ & KP793685 \\
\hline 5 & Leutea elbursensis Mozaff. & $\begin{array}{l}\text { Iran: Tehran, Karaj, 35.933, 51.067, } \\
1600 \mathrm{~m}\end{array}$ & $\begin{array}{l}\text { Valiejo-Roman et al., } \\
526 \text { (MW) }\end{array}$ & $\begin{array}{l}\text { AY941276 } \\
\text { AY941304 }\end{array}$ \\
\hline 6 & Leutea elbursensis Mozaff. & Iran: NW of Tehran, Souleghan & Mozaffarian \& Jamzad 33570 (TARI) & KJ660832 \\
\hline 7 & $\begin{array}{l}\text { Leutea glaucopruinosa (Rech. fil.) } \\
\text { Akhani \& Salimian }\end{array}$ & Iran: Mazandaran & $\begin{array}{l}\text { Termeh \& Zargari 040483-E (W } \\
\text { 0023608) }\end{array}$ & KJ660833 \\
\hline 8 & Leutea petiolaris (DC.) Pimenov & Iran: Azarbayejan & Mozaffarian \& Massoumi 78152 (TARI) & KJ660836 \\
\hline 9 & Leutea petiolaris (DC.) Pimenov & $\begin{array}{l}\text { Iran: Tehran, } \\
35.767,51.950,2400 \mathrm{~m}\end{array}$ & Valiejo-Roman et al. 63 (MW) & $\begin{array}{l}\text { AY941278 } \\
\text { AY941306 }\end{array}$ \\
\hline 10 & Leutea rechingeri (Leute) Pimenov & Iraq: Suleymanieh, Mt. Algurd & Rechinger 11416 (W 05825) & KJ660838 \\
\hline 11 & Leutea cupularis (Boiss.) Pimenov & Iran: SW, Dena Mts., 2900-3100 m & $\begin{array}{l}\text { Valiejo-Roman et al. } \\
235 \text { (MW) }\end{array}$ & $\begin{array}{l}\text { AY941277 } \\
\text { AY941305 }\end{array}$ \\
\hline 12 & Leutea cupularis (Boiss.) Pimenov & Iran: SW, Dena Mts., 3500-3900 m & Assadi \& Mozaffarian. 31236 (TARI) & KJ660831 \\
\hline 13 & Leutea polyscias Pimenov & Iran: Manjil, 1650 m & Mozaffarian 64227 (TARI) & KJ660837 \\
\hline 14 & Leutea gracillima Pimenov & Iran: NE, Golestan Park. & Akhani 12060 (W 1999-03655) & KJ660834 \\
\hline 15 & Leutea nematoloba (Rech.f.) Pimenov & Iran: N, Chalus Valley. & Rechinger \& Rechinger 6668 (W 02835) & KJ660835 \\
\hline 16 & Ferula violaceae Korovin & SW Asia & Valiejo-Roman et al., 119899 (MW) & AF077891 \\
\hline 17 & Ferula olivacea (Diels) H. Wolff. & China & Chamberlain, Ming, Yuan \& al. 229 (E) & EF560691 \\
\hline
\end{tabular}

temperature, $60^{\circ} \mathrm{C}$ with $7^{\circ} \mathrm{C}$ temperature increase per minute, up to $230^{\circ} \mathrm{C}$; injector and detector temperatures, $280^{\circ} \mathrm{C}$; volume injected, $0.1 \mu \mathrm{L}$ of the oil; split ratio, 1:25. In addition, the following MS operating parameters were used: ionization potential, $70 \mathrm{ev;}$ resolution, 1000; ion source temperature, $200{ }^{\circ} \mathrm{C}$. Components in the oil were identified based on GC retention indices relative to n-alkanes and computer matching with the Wiley 275.L library, as well as by comparison of the fragmentation patterns of the mass spectra with those reported in the literature (Adams 1995, Masoudi et al. 2004, Alipour et al. 2015).

SPSS v. 20 (IBM corporation) was used to perform cluster analyses based on the chemical components of essential oils with Ward's method (Ward 1963).

\section{Results}

Figure 1 shows the phylogeny of different species of Leutea based on the Bayesian analysis (BA) of the ITS region. Two species of Ferula i.e. F. violacea and F. olivacea, were included in the tree as outgroups. Posterior probabilities (PP) are indicated by numbers above each clade. Bootstrap supports (BS) for those clades also retrieved in the maximum parsimony (MP) analysis are indicated by the numbers below each clade (Fig. 1). As seen on the phylogenetic tree, species of the genus Leutea are mainly grouped into two clades: clade A) a firmly supported clade including all samples of $L$. elbursensis with posterior probability $(\mathrm{PP})=1.00$ and bootstrap support $(\mathrm{BS})=100 \%$, and clade B) another well supported clade including a polythomy of eight species with PP $=1.00$ and $\mathrm{BS}=85 \%$. Leutea elbursensis is sister to rest of species (Fig. 1). All our three accessions of L. elbursensis together with another two samples taken from the Genbank (both from NW of Tehran) formed a monophyletic clade. All four samples are taken from a relatively small locality in N Iran (central Elburz) with distances of less than $100 \mathrm{~km}$ among them. The monophyletic clade B presents a polythomy of different species. These include three samples of $L$. petiolaris, two samples of $L$. cupularis, and one sample of each species L. galucopruinosa, L. rechingeri, L. polyscias, L. avicennae, $L$. gracillima and L. nematoloba (Fig. 1). Two samples of L. cupularis collected from the Dena mountain ranges (SW Iran) formed a monophyletic clade with strong support $(\mathrm{PP}=1$, $\mathrm{BS}=85 \%$ ). Different samples of $L$. petiolaris did not form a monophyletic clade. The results showed that our samples from the area clearly belong to two different species. Phylogenetic relationships within this clade are not essentially resolved. This clade consists of samples collected from a larger region involving distances of hundreds of kilometres.

In the selective PCR of AFLP analysis, the E38-M57 primer combination yielded 62 bands, the E45-M54 primer combination 36 bands, and the E40-M55 primer combina- 


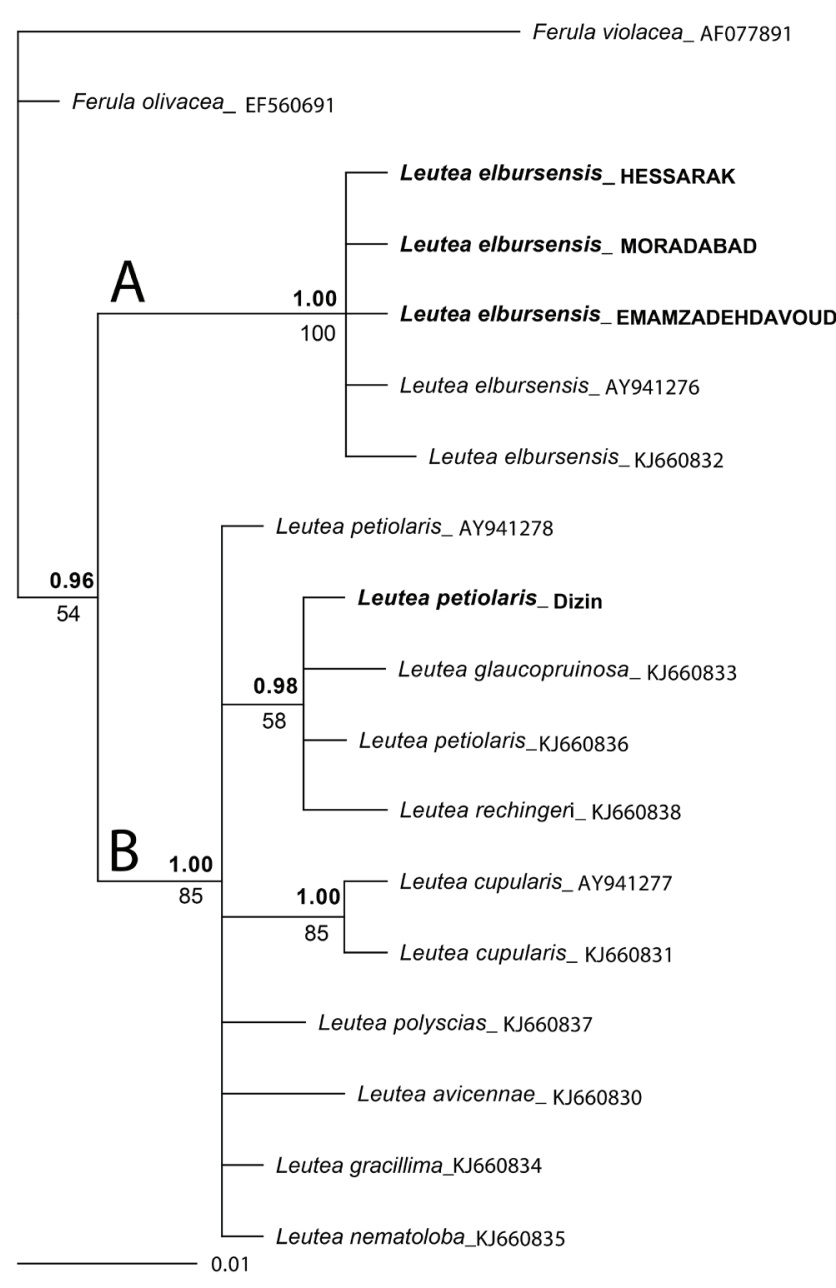

Fig. 1. Phylogenetic tree obtained from the Bayesian analysis of the internal transcribed spacer region of different species of Leutea alongside two Ferula species as outgroup (total characters $=442$; constants $=299$; parsimony informatives $=60$. Model of evolution $=\mathrm{SYM}+\mathrm{G} ; \mathrm{A}-\mathrm{C}$ constitution rate $=1.7930 ; \mathrm{A}-\mathrm{G}$ constitution rate $=2.2561 ; \mathrm{A}-\mathrm{T}$ constitution rate $=2.0384 ; \mathrm{C}-\mathrm{G}$ constitution rate $=$ 0.4189 ; $\mathrm{C}-\mathrm{T}$ constitution rate $=5.9481 ; \mathrm{G}-\mathrm{T}$ constitution rate $=$ 1.0000. Gamma distribution rate $=0.6465$ ). Numbers above clades are posterior probabilities. Numbers below clades are the bootstrap supports (100 replicates) for those clades retrieved in the maximum parsimony analyses (bootstrap supports less than $50 \%$ are not shown). tion 36 bands. The AMOVA test results showed that of $100 \%$ total variation, $34 \%$ was among regions, $6 \%$ was among populations and $60 \%$ was within populations (Tab. 2). Analysis of the populations using Structure 2.3.4 software showed that all individuals belonged to two different clusters showed here with different colours (Fig. 2). As seen in Figure 2, individuals of L. petiolaris from "Dizin" population are homogenous in their genetic structure (cluster "a"). All six individuals collected from "Dizin" (L. petiolaris) had genetic structures 90-100\% consisting of cluster "a" alleles. Genetic profiles of three populations of $L$. elbursensis mainly consist of a different cluster (cluster b). Genetic structures of all six individuals from the "Emamzadeh-Davoud" population consisted $100 \%$ of alleles from cluster $b$. Except for one individual from the "Hessarak" population and another one individual from the "Morad-Abad" population, all other individuals from those two populations were $97-100 \%$ made by alleles from cluster "b". AFLP profiles of two species are clearly different. This clearly shows that two different species are distributed in the area $\mathrm{N}$ and NW of Tehran.

This is the first report of chemical composition of essential oils extracted from the ripened fruits of L. elbursensis. The essential oils obtained from dried fruits were clear, pale yellow liquids. The essential oil content of L. elbursensis was between $0.5 \%$ (w/w; in the Emamzadeh-Davoud population) - $0.6 \%$ (w/w; in Hessarak and Moradabad populations). Between 15 to 29 natural compounds were identified, accounting for 98.7 - 100\% of the oils (Tab. 3). Ripened fruits of L. petiolaris collected for two successive years did not yield

Tab. 2. AMOVA test results showing the variations of Leutea elbursensis from northern Iran: within populations, among populations (pops) and among regions. Df - degrees of freedom; SS- sum of the squares; MS - mean squares; Est. Var. - estimation of variance.

\begin{tabular}{lccccc}
\hline Source & Df & SS & MS & Est. Var. & $\%$ \\
\hline Among regions & 1 & 124.972 & 124.972 & 10.602 & 34 \\
Among pops & 2 & 59.111 & 29.556 & 1.798 & 6 \\
Within pops & 20 & 375.333 & 18.767 & 18.767 & 60 \\
Total & 23 & 559.417 & 173.295 & 31.167 & 100 \\
\hline
\end{tabular}

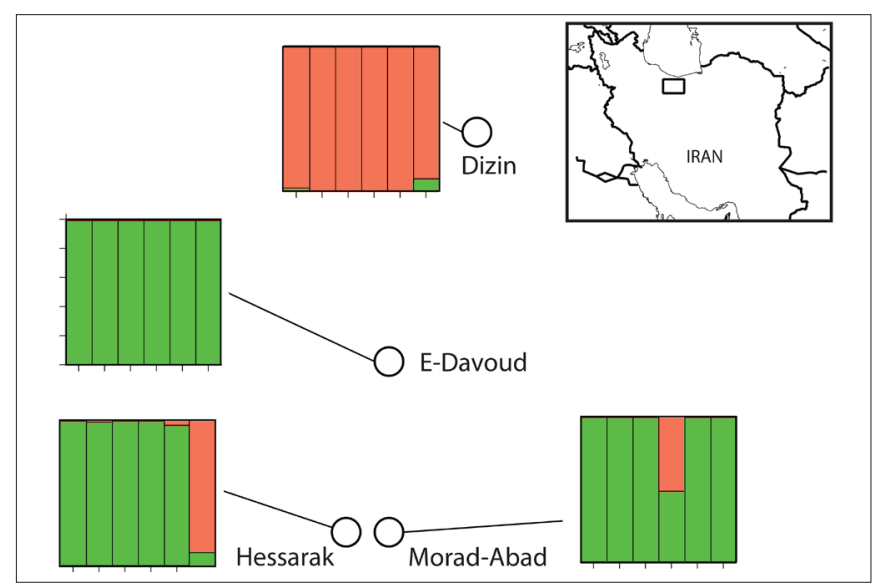

Fig. 2. Amplified fragment length polymorphism finger printing results showing the genetic profile of 24 individuals collected from northern Iran (Leutea elbursensis from Hessarak, Morad-Abad and Emamzadeh (E-) Davoud; L. petiolaris from Dizin). 
Tab. 3. Composition of the essential oils of different populations of Leutea elbursensis from northern Iran. KI - Kovats index.

\begin{tabular}{|c|c|c|c|c|c|}
\hline \multirow{2}{*}{ Number } & \multirow{2}{*}{ Component name } & \multirow{2}{*}{ KI } & \multicolumn{3}{|c|}{ Percentage of components in each population } \\
\hline & & & Morad-Abad & Hessarak & Emamzadeh-Davoud \\
\hline 1 & $\alpha$-Thujene & 930 & 1.38 & 0.54 & 1.2 \\
\hline 2 & a-Pinene & 939 & 39.77 & 33.18 & 43.22 \\
\hline 3 & Camphene & 954 & 1.32 & 0.57 & 1.24 \\
\hline 4 & Thuja-2,4 (10)-diene & 960 & 0.14 & 0 & 0 \\
\hline 5 & Sabinene & 975 & 2.05 & 0.71 & 1.9 \\
\hline 6 & $\beta$-Pinene & 979 & 36.1 & 32.4 & 40.9 \\
\hline 7 & Myrcene & 990 & 0 & 1 & 0 \\
\hline 8 & P-Cymene & 1024 & 0.35 & 0 & 0 \\
\hline 9 & Limonene & 1029 & 3.14 & 1.9 & 3.5 \\
\hline 10 & $\beta$-Phelandrene & 1029 & 0.91 & 0.64 & 0 \\
\hline 11 & Cineol & 1031 & 0.78 & 0 & 0.8 \\
\hline 12 & $z$ - $\beta$-Ocimene & 1037 & 0.18 & 0 & 0 \\
\hline 13 & $\gamma$-Terpinene & 1059 & 0.19 & 0 & 0 \\
\hline 14 & a-Campholenal & 1126 & 0.41 & 0.53 & 0 \\
\hline 15 & Trans-Pinocarveol & 1139 & 3.5 & 0 & 1.3 \\
\hline 16 & Trans- Verbenol & 1144 & 0.16 & 5.62 & 0 \\
\hline 17 & Pinocarvone & 1164 & 0.9 & 1.52 & 0.8 \\
\hline 18 & $\alpha$-Terpineol & 1188 & 0.33 & 0.78 & 0.46 \\
\hline 19 & Myrtenol & 1195 & 1.34 & 5.6 & 1.2 \\
\hline 20 & Verbenone & 1205 & 0.19 & 0 & 0 \\
\hline 21 & endo-Fenchyl acetate & 1220 & 1.32 & 3.02 & 0.8 \\
\hline 22 & Isobornyl acetate & 1285 & 1.36 & 4.95 & 1.73 \\
\hline 23 & cis-Pinocarvyl acetate & 1312 & 0.25 & 0.75 & 0 \\
\hline 24 & Myrtenyl acetate & 1326 & 0.57 & 2.12 & 0.45 \\
\hline 25 & Neryl acetate & 1361 & 0.26 & 2.01 & 0.5 \\
\hline 26 & Daucene & 1381 & 0.52 & 0.81 & 0 \\
\hline 27 & $a$-Trans Bergamotene & 1434 & 0.1 & 0 & 0 \\
\hline 28 & $z$ - $\beta$-Farnesene & 1442 & 0.15 & 0 & 0 \\
\hline 29 & Pentadecane & 1500 & 0.2 & 0 & 0 \\
\hline 30 & Trans- $\beta$-Guaiene & 1502 & 0.2 & 0 & 0 \\
\hline 31 & a-Copaen-11-01 & 1539 & 0 & 0.8 & 0 \\
\hline Total & & & 98.07 & 99.45 & 100 \\
\hline
\end{tabular}

any traceable essential oil. The highest number of components was identified in the Moradabad population (29 components). We also identified 20 components for the "Hessarak" population. The smallest number of components was 15 and was identified in the "Emamzade-Davoud" population. The main components identified in our three populations were $\alpha$-pinene $(33.18-43.22 \%)$ and $\beta$-pinene (32.4 $-40.9 \%)$. There were few other important but less abundant components (ca. $5 \%$ or more) i.e. myrtenol $(5.6 \%)$, transverbenol (5.6\%) and isobornyl acetat (4.95\%) which were identified only in the Hesarak population.

\section{Discussion}

Different populations of L. elbursensis had identical ITS sequences and relatively similar genetic structures. Its segregation from L. petiolaris was supported by ITS and AFLP data. This segregation is also supported by morphological and geographical evidence. Leutea elbursensis has unique tall flowering stems $1.5-3 \mathrm{~m}$ high, while other species are clearly shorter (up to $1.5 \mathrm{~m}$ high). Leutea species have an allopatric distribution. Leutea elbursensis is endemic to N and NW Tehran, especially the rocky slopes of Souleghan valley (Mozaffarian 2007). Despite the similarities in morphology, ITS sequence and genetic structure, the essential oil contents of our three populations were highly variable.

The results showed that Leutea plants distributed in the region $\mathrm{N}$ and NW of Tehran do not belong to a single species. Pimenov (1987) mistakenly identified all herbarium material collected from the area under L. cupularis. We showed here that they belong to two different species. Our results are in agreement with Mozaffarian (2007), who identified the material from "central Elburz" under two different species i.e. L. elbursensis and L. petiolaris. These results indicate that $F$. petiolaris and F. elbursensis are two different entities. Regardless of the disputable taxonomic position of the genus Leutea, our results clearly showed that L. elbursensis is a distinct species sister to the rest of Leutea species (Fig. 1). 
The genus Ferula s. 1. (including Leutea) in Iran is widely studied chemically. We compared our results to one of the most comprehensive studies, that performed by Kanani et al. (2011) on 18 different populations belonging to different species of Ferula (Fig. 3). Our analysis showed that the essential oil profile of our three samples was most similar to that of a sample from F. stenocarpa Boiss. \& Hausskn. All these four samples formed a distinct group "rich" and "balanced" of $\alpha-$ Pinene $(33.18-48.8 \%)$ and $\beta$-Pinene $(30.1-40.9 \%)$, and this group is also related to another group consisted of F. gummosa Boiss. and F. galbaniflua Boiss. \& Buhse with a higher amount of $\beta$-Pinene $(26.8-69.2 \%)$ and a lower amount of $\alpha$ Pinene (1.4-33.9\%) (Ghannadi and Amree 2002, Ghasemi et al. 2005, Jahansouz et al. 2008, Talebi Kouyakhi et al. 2008, Kanani et al. 2011). The chemical composition of essential oils of Leutea glaucopruinosa Rech.f. Yassa et al. (2003) showed no close similarity to our samples ("LG" in Figure 3). The chemical composition of Dorema glabrum Fisch. \& C. A. Mey. Delnavazi et al. (2015) is similar to that of some Ferula species. Comparing the dendrogram shown in Figure 3 with the Leutea phylogeny (Fig. 1) and the phylogeny obtained by Kurzyna-Mlynik et al. (2008), it becomes clear that similarities in chemical composition of the essential oils of the "Ferula group" does not reflect the phylogenies based on the molecular data.

Regarding their uniform ITS sequences and similar AFLP profiles, the essential oil profiles of different populations of L. elbursensis were very variable, most probably as the result of different ecological conditions. The chemical composition of essential oils in the family Apiaceae can be very variable, especially according to the plant parts the oils are extracted from (Kanani et al. 2011). Alipour et al. (2015) reported different chemical compositions for the essential oils extracted from different parts of L. cupularis. They found following major components in different parts of the plant: $ð$-2-Carene $(15.81 \%)$ and DL-Limonene (25.04\%) in flowers; $\beta$-Pinene (13.87\%), $\beta$-Ocimene (9.05\%), Bornyl angelate $(6.55 \%)$ and allo-Ocimene $(6.08 \%)$ in leaves; and $ð$-3-Carene $(8.38 \%)$, a-Terpinyl isobutyrate (8.69\%) and Bornyl angelate (7.45\%) in stems. In addition, the chemical composition of essential oil can be highly affected by ecological conditions and genetic structure (Munoz-Bertomeu et al. 2007). Therefore, we here suggest that a standard method should be used for analyzing and interpreting the data obtained from essential oils. As mentioned above, different parts of the plants might yield essential oils with different contents. Ripened fruits of the members of the family Apiaceae could be an appropriate

\section{References}

Adams, R. P., 1995: Identification of essential oil components by gas chromatography/mass spectrometry. Allured Publishing Corporation, Illinois.

Alipour, Z., Taheri, P., Samadi, N., 2015: Chemical composition and antibacterial activity of the essential oils from flower, leaf and stem of Ferula cupularis growing wild in Iran. Pharmaceutical Biology 53, 483-487.

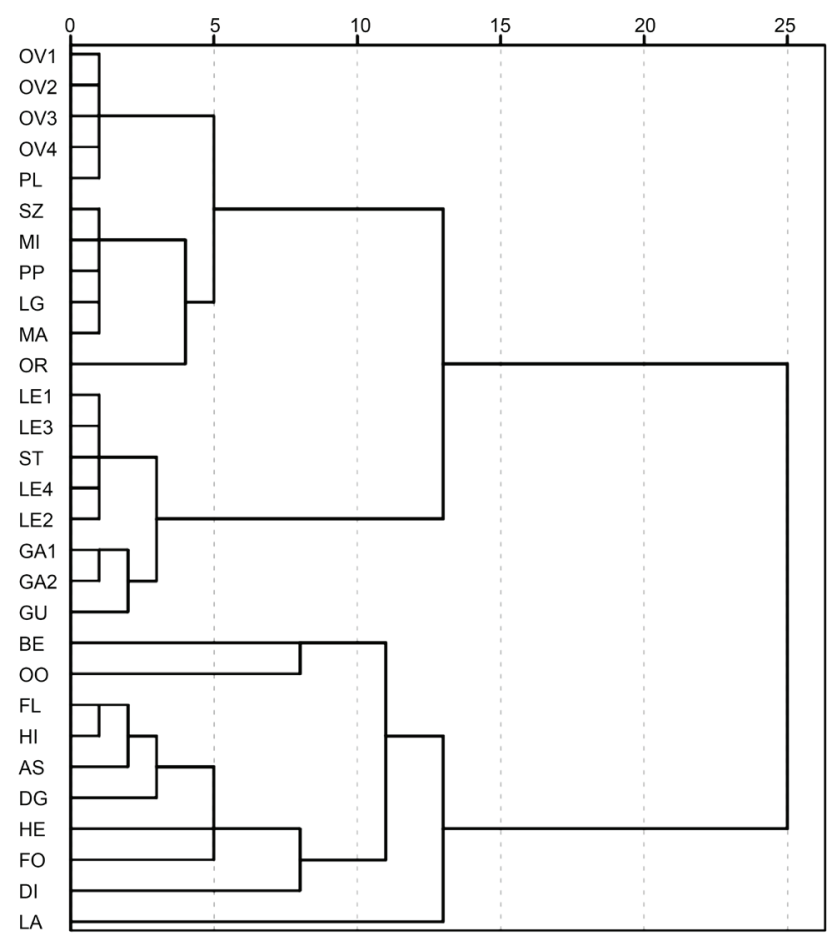

Fig. 3. Dendrogram showing classification of different populations of Ferula spp. based on the similarities in essential oil composition. Amount of components for Leutea populations are shown in Table 3 and for other populations are presented in Kanani et al. (2011). Numbers on the $\mathrm{x}$-axis represent values of dissimilarity. LE1 - Leutea elbursensis, Moradabad; LE2 - L. elbursensis, Hessarak; LE3 - L. elbursensis, Emamzadeh-Davoud); LE4 - L. elbursensis, Karaj; OV1-4 - Ferula ovina; SZ - F. szowitsiana; MI - F. microcolea; PP - F. persica var. persica; PL - F. persica var. latisecta; ST - F. stenocarpa; GA1-2 - F. galbaniflua; GU - F. gummosa; BE - F. behboudiana; OO - F. oopoda; HI - F. hirtella; MA - F. macrocolea; FL - F. flabelliloba; AS - F. assa-foetida; OR - F. orientalis; HE - F. hezarlalehzarica; FO - F. foetida; DI - F. diversivittata; LA - F. latisecta); LG - L. glaucopruinosa; DG - Dorema glabrum.

source for obtaining essential oils. Regarding those issues, we here suggest that the chemical composition of essential oils cannot be used as a trusted taxonomic tool, at least in case of the "Ferula-group".

\section{Acknowledgments}

The authors would like to thank Mrs R. Amini for her help in collecting part of the material.

Benjak, A., Ercisli, S., Vokurka, A., Maletic, E., Pejic, I., 2005: Genetic relationships among grapevine cultivars native to Croatia, Greece and Turkey. Vitis 44, 73-77.

Boissier, P. E., 1872: Flora Orientalis. Apud H. Georg, Bibliopolam Lugdhni. Genevae \& Basileae.

Canan, I., Gundogdu, M., Seday, U., Oluk, C. A., Karasahin, Z., Eroglu, E. C., Yazici, E., Unlu, M., 2016: Determination of antioxidant, total phenolic, total carotenoid, lycopene, ascorbic 
acid, and sugar contents of Citrus species and mandarin hybrids. Turkish Journal of Agriculture and Forestry 40, 894-899.

De Candolle, A. P., 1830: Prodromus systematis naturalis regni vegetabilis, sive, Enumeratio contracta ordinum generum specierumque plantarum huc usque cognitarium, juxta methodi naturalis, normas digesta, Sumptibus Sociorum Treuttel et Wuertz. Paris.

Delnavazi, M. R., Hadjiakhoondi, A., Delazar, A., Ajani, Y., Tavakoli, S., Yassa, N., 2015: Phytochemical and antioxidant investigation of the aerial parts of Dorema glabrum Fisch. \& C. A. Mey. Iranian Journal of Pharmaceutical Research 14, 925-931.

Douzery, E. J. P., Pridgeon, A. M., Kores, P., Linder, H. P., Kurzweil, H., Chase, M. W., 1999: Molecular phylogenetics of Diseae (Orchidaceae): a contribution from nuclear ribosomal ITS sequences. American Journal of Botany 86, 887-899.

Ercisli, S., 2009: Apricot culture in Turkey. Scientific Research and Essays 4, 715-719.

Ercisli, S., Tosun, M., Duralija, B., Voca, S., Sengul, M., Turan, M., 2010: Phytochemical content of some black (Morus nigra L.) and purple (Morus rubra L.) mulberry genotypes. Food Technology and Biotechnology 48, 102-106.

Ghannadi, A. and Amree, A. S., 2002: Volatile constituents of Ferula gumosa from Iran. Journal of Essential Oil Research 14, 420.

Ghasemi, Y., Faridi, P., Mehregan, I., Mohagheghzade, A., 2005: Ferula gummosa fruits: an aromatic antimicrobial agent. Chemistry of Natural Compounds 41, 311-314.

Hay, R. K. M., Waterman, P. G., 1993: Volatile oil crops: their biology, biochemistry and production, Longman Scientific \& Technical, Essex.

Huelsenbeck, J. P., Ronquist, F., 2001: MRBAYES: Bayesian inference of phylogeny. Bioinformatics 17, 754-755.

Jahansouz, F., Ebrahimzade, H., Najafi, A. A., Naghavi, M. R., Kouyakhi, E. T., Farzaneh, H., 2008: Evalution of positive and negative effects of essential oil samples of Ferula gummosa Boiss. on two plant phytopathogenic fungi, Iranian Journal of Medicinal and Aromatical Plants 24, 10-17.

Kanani, M. R., Rahiminejad Ranjbar, M. R., Kazempour, O. Sh., Mozaffarian, V., 2013: Cladistical study assessement of evolutionary process based on morphological data in of Ferula L. in Iran. Taxonomy and Biosystematic Journal 14, 53-66.

Kanani, M. R., Rahiminejad Ranjbar, M. R., Kazempour, O. Sh., Mozaffarian, V., Kazempour, O. Sh., 2011: Chemotaxonomic significance of the essential oils of 18 Ferula species (Apiaceae) from Iran. Chemistry \& Biodiversity 8, 503-517.

Kurzyna-Młynik, R., Oskolski, A. A., Downie, S. R., Kopacz, R., Wojewódzka, A., Spalik, K., 2008: Phylogenetic position of the genus Ferula (Apiaceae) and its placement in tribe Scandiceae as inferred from nrDNA ITS sequence variation. Plant Systematics and Evolution 274, 47-66.

Maddison, D. R., Maddison, W. P., 2000: MacClade 4. Sinauer Associates, Sunderland, Massachusetts.

Masoudi, Sh., Rustaiyan, A., Ameri, N., 2004: Volatile oils of Ferulago phialocarpa Rech. f. et H. Reidi. and Leutea elbursensis Mozaffarian from Iran. Journal of Essential Oil Research 16, 143-144.

Mehregan, I., Ghannadi, A., 2013: Essential oil analysis of Haussknechtia elymaitica Boiss fruits, an endemic plant from Iran. Revista De Chimie 64, 81-82.

Mozaffarian, V., 2007: Flora of Iran, no. 54 (Umbelliferae). Research Institute of Forests and Rangelands, Tehran (in Persian).
Munoz-Bertomeu, J., Arrillaga, I., Segura, J., 2007: Essential oil variation within and among natural populations of Lavandula latifolia and its relation to their ecological areas. Biochemical Systematics and Ecology 35, 479-488.

Olivier, D. K., van Wyk, B. E., 2013: The major diterpenoids of the genus Arctopus (Apiaceae) with notes on their chemotaxonomic and medicinal significance. South African Journal of Botany 85, 94-98.

Panahi, M., Banasiak, L., Piwczynski, M., Puchalka, R., Oskolski, A., Krzysztof, K., 2015: Phylogenetic relationships among Dorema, Ferula and Leutea (Apiaceae: Scandiceae: Ferulinae) inferred from nrDNA and cpDNA noncoding sequences. Taxon $64,770-783$.

Peakall, R., Smouse, P. E., 2012: GenAlEx 6.5: genetic analysis in Excel. Population genetic software for teaching and research - an update. Bioinformatics 28, 2537-2539.

Pimenov, M. G., 1987: Leutea Pimenov. In: Rechinger KH (ed.), Flora Iranica 162, 445-450, Akademische Druck- und Verlagsanstalt, Graz.

Pimenov, M. G., Leonov, M. V., 1993: The genera of the Umbelliferae. Royal Botanic Gardens, Kew, Richmond, Surrey.

Pritchard, J. K., Stephens, M., Donnelly, P., 2000: Inference of population structure using multilocus genotype data. Genetics 155, 945-959.

Rop, O., Ercisli, S., Mlcek, J., Jurikova, T., Hoza, I., 2014: Antioxidant and radical scavenging activities in fruits of 6 sea buckthorn (Hippophae rhamnoides L.) cultivars. Turkish Journal of Agriculture and Forestry 38, 224-232.

Safaeian, L., Ghannadi, A., Haghjoo-Javanmard, Sh., Vahidian, M. H., 2015: The effect of hydroalcoholic extract of Ferula foetida stems on blood pressure and oxidative stress in dexamethasone-induced hypertensive rats. Research in Pharmaceutical Sciences 10, 326-334.

Scalone, R., Albach, D. C., 2012: Degradation of sexual reproduction in Veronica filiformis after introduction to Europe. BioMed Central Evolutionary Biology, 12.1, 233.

Stevens, P. F., 2012: Angiosperm phylogeny website. Version 12, retrived April 10, 2015 from http://www.mobot.org/MOBOT/ research/APweb/

Swofford, D. L., 2002: PAUP*, Phylogenetic analysis using parsimony (*and other methods). Sinauer Associates, Sunderland, Massachusetts.

Talebi Kouyakhi, E., Naghavi, M. R., Alayhas, M., 2008: Study of the essential oil variation of Ferula gummosa samples from Iran. Chemistry of Natural Compounds 44, 124-126.

Vos, P., Hogers, R., Bleeker, M., Reijans, M., Van de Lee, T., Hornes, M., Frijters, A, Peleman, J., Kuiper, M., 1995: AFLP: a new technique for DNA fingerprinting. Nucleic Acids Research 23, 4407-4414.

Ward, J. H., 1963: Hierarchical grouping to optimize an objective function. Journal of the American Statistical Association $58,236-244$.

Yassa, N., Akhani, H., Agaahmadi, M., Salimian, M., 2003: Essential oils from two endemic species of Apiaceae from Iran. Zeitschrift fuer Naturforschung 58c, 459-463.

Zorenc, Z., Veberic, R., Stampar, F., Koron, D., Mikulic-Petkovsek, M., 2016: Changes in berry quality of northern highbush blueberry (Vaccinium corymbosum L.) during the harvest season. Turkish Journal of Agriculture and Forestry 40, $855-867$. 